\title{
Analysis of the efficiency of energy systems of long-distance energy transport
}

\author{
E. A. Tyurina ${ }^{1,2, *}, A . S$. Mednikov $^{1}, P . Y$. Elsukov $^{1}$, and $S . N$. Sushko $^{2}$ \\ ${ }^{1}$ Melentiev Energy Systems Institute SB RAS, Irkutsk, Russia \\ ${ }^{2}$ Irkutsk National Research Technical University, Irkutsk, Russia
}

\begin{abstract}
The article presents the results of the comparative efficiency of energy systems for the transfer of natural gas energy over long distances from large deposits to final consumers. The result of the research is the limits of competitiveness of systems based on direct current transmissions, gas pipelines, a promising technology for converting natural gas to synthetic liquid fuel (SLF) - methanol - on installations of combined production of SLF and electricity based on their detailed mathematical models.
\end{abstract}

\section{Introduction}

A large portion of fuel and energy resources, concentrated in the eastern regions of Russia allow one to both meet the domestic demands and to export energy carriers to the countries of Northeast Asia (NEA) on a substantial scale. However, the distances between the regions having considerable fuel energy resources reserves and potential regions of their consumption in the NEA countries are great and can reach 5-6 thousand $\mathrm{km}$. Therefore, the economic efficiency of energy resources export is in many ways determined by transport expenses. In these conditions selection of optimal technologies for transporting energy resources is very important.

The paper presents result of the studies performed at the Energy Systems Institute (ESI), Siberian Branch of RAS on the economic efficiency of different technologies for energy resources transport. The following technologies have been considered.

1. Transport of natural gas by pipelines.

2. Electricity production from natural gas and its transmission by the high voltage direct current transmission (HVDC) line.

3. Natural gas conversion to methanol and its transport by pipelines or railway.

It is necessary to stress the following specific features of these options for energy transport. In essence, investments in gas pipelines are in direct proportion to their length, whereas in the options of electricity and methanol transport a sizeable part of investments does not depend on the distance of transport. These are investments in methanol production, thermal power plants and terminal converter substations of HVDC lines. In this case the specific cost of linear parts of the methanol pipelines and HVDC transmission lines is lower per unit of the equivalent volume of energy transmitted than for gas pipelines. The volumes of gas and methanol which have the same heating value are considered to be equivalent and the gas volume is taken equivalent to the amount of electricity that can be produced from it.

Gas pipelines with diameters of $1020 \mathrm{~mm}, 1220 \mathrm{~mm}$ and $1420 \mathrm{~mm}$ are studied in the paper. Natural gas will be converted to methanol at energy-technological installations (ETI) for combined production of methanol and electricity which have been investigated at ESI SB RAS for a number of years $[1,2]$. Methanol is planned to be transported by the methanol pipelines with diameters of 1020 and $1220 \mathrm{~mm}$. Compressor stations of gas pipelines will be operated by gas turbines and pumping stations of methanol pipelines will be power-driven. Electricity from natural gas will be produced at the upto-date combined-cycle power plants with a net efficiency of $55 \%$. Natural gas price at the production site was taken equal to $30 \mathrm{USD} /$ thousand $\mathrm{m} 3$. HVDC will be transmitted by single-circuit lines with a rated capacity of $3000 \mathrm{MW}$ and voltage of $\pm 600 \mathrm{kV}$.

Each considered technology of energy conversion and transport was studied on mathematical models constructed. Their economic efficiency was examined for different combinations of the initial technical and economic information.

\section{Methods and approaches to the study}

The studies were carried out at two stages.

Stage 1 was intended for optimization of transfer capability and expenses to transport a unit of energy for the gas and methanol pipelines with different diameters as a function of the specific cost of their linear sections and as a function of electricity cost at the line beginning for HVDC lines. The optimal capacities of pipelines and transmission lines were determined by minimization of the cost of per-unit energy transport at the set level of

\footnotetext{
* Corresponding author: tyurina@ isem.irk.ru
} 
investment return rate (IRR) defined in accordance with [3].

Variation of the capacity of gas and methanol pipelines depends on variation of the distance between pumping stations and change in the transfer capability of HVDC lines - on change in the capacity of terminal converter substations.

The optimization problem in general is formulated as follows.

$$
\min _{C_{e n, Q, x}} C_{e n}
$$

subject to

$$
\begin{aligned}
& H(Q, x, y, s)=0 \\
& G(Q, x, y, s) \geq 0
\end{aligned}
$$

$$
\operatorname{IRR}\left(C_{e n}, Q, x, y, s\right)=I R R_{z}
$$

where $C_{e n}$ - price of the per-unit energy transportation, $Q$ - volume of the energy carrier transported, $x$ - vector of optimized (independent) parameters of the energy transportation system, $y$ - vector of calculated parameters, $s$-vector of initial technical and economic data, $I R R_{z}$ - set value of the internal return rate, $H$ vector function of the equality constraints, $G$ - vector function of the inequality constraints.

The basic initial data applied in calculations are presented in Tables 1, 2 [2, 4-6].

It should be underlined that the optimal capacities of gas pipelines with the indicated diameters differ from conventionally accepted ones. For gas pipeline with a $1020 \mathrm{~mm}$ diameter the optimal flow rates range between
11-14 billion $\mathrm{m}^{3}$ per year, with a $1220 \mathrm{~mm}$ diameter 23-32 billion $\mathrm{m}^{3}$ and with a $1420 \mathrm{~mm}$ diameter - 32-43 billion $\mathrm{m}^{3}$ per year.

Depending on specific investments in the linear sections specific expenditures on natural gas transportation for $1000 \mathrm{~km}$ by the gas pipelines with a $1420 \mathrm{~mm}$ diameter are 24-38 USD/t c.e. per $1000 \mathrm{~km}$, with a $1220 \mathrm{~mm}$ diameter - 28-42 USD/t c.e per 1000 $\mathrm{km}$, with a $1020 \mathrm{~mm}$ diameter - 32-58 USD/t c.e. per $1000 \mathrm{~km}$.

In comparison to gas pipelines the optimal capacity of methanol pipelines is dependent on change in specific investments in the linear part to a lesser extent. Specific costs on methanol transport as a function of specific investments in the linear part for the methanol pipeline with a $1020 \mathrm{~mm}$ diameter range between 15-27 USD/t c.e. per $1000 \mathrm{~km}$, with a $1220 \mathrm{~mm}$ diameter - 10-18 $\mathrm{USD} / \mathrm{t}$ c.e. per $1000 \mathrm{~km}$.

Thus, specific costs on transport of per-unit energy in methanol are 2-3 times lower than costs on transport of per-unit energy in natural gas and the energy capacity of methanol pipelines is more than twice as high as that of gas pipelines of the same diameter.

The optimal capacity of HVDC lines is shown to essentially depend on the electricity cost at the inlet (change from 2800 to $4700 \mathrm{MW}$ ). Specific costs on power transmission by HVDC lines account for 1.18$1.67 \mathrm{cent} / \mathrm{kWh}$ per $1000 \mathrm{~km}$.

At stage 2 the possible ranges for change in price of electricity, natural gas and methanol in the North-East Asian countries were estimated and IRR for these energy

\begin{tabular}{|c|c|c|c|c|c|c|}
\hline \multirow[t]{2}{*}{ Indices } & \multirow[t]{2}{*}{ Units } & \multicolumn{3}{|c|}{ Gas pipeline diameters } & \multicolumn{2}{|c|}{$\begin{array}{l}\text { Methanol pipeline } \\
\text { diameters }\end{array}$} \\
\hline & & $1420 \mathrm{~mm}$ & $1220 \mathrm{~mm}$ & $1020 \mathrm{~mm}$ & $1220 \mathrm{~mm}$ & $1020 \mathrm{~mm}$ \\
\hline 1.Nominal pressure & $\mathrm{MPa}$ & 7.4 & 7.4 & 5.4 & 5.4 & 5.4 \\
\hline $\begin{array}{l}\text { 2.Number of rated capacity } \\
\text { utilization hours per year }\end{array}$ & hours & \multicolumn{5}{|c|}{8000} \\
\hline 3.Base specific cost of a linear part & $\begin{array}{l}\text { million } \\
\text { USD/km }\end{array}$ & 3.4 & 2.3 & 1.5 & 2.15 & 1.5 \\
\hline $\begin{array}{l}\text { 4.Fixed component of investments } \\
\text { in pumping station }\end{array}$ & $\begin{array}{c}\text { million } \\
\text { USD } \\
\end{array}$ & 31.5 & 22.5 & 13.5 & 15 & 13.5 \\
\hline $\begin{array}{l}\text { 5.Variable component } \\
\text { investments in pumping station }\end{array}$ & $\mathrm{USD} / \mathrm{kW}$ & 300 & 300 & 300 & 600 & 600 \\
\hline $\begin{array}{l}\text { 6.Specific fuel consumption by gas } \\
\text { turbines for drive of compressor } \\
\text { stations }\end{array}$ & g c.e. $/ \mathrm{kWh}$ & \multicolumn{3}{|c|}{384} & \multicolumn{2}{|c|}{ - } \\
\hline $\begin{array}{l}\text { 7.Electricity price of electric drive } \\
\text { of pumping stations }\end{array}$ & cent $/ \mathrm{kWh}$ & \multicolumn{3}{|c|}{-} & \multicolumn{2}{|c|}{5} \\
\hline $\begin{array}{l}\text { 8.Calculated low heating value of } \\
\text { natural gas or methanol }\end{array}$ & $\begin{array}{c}\mathrm{MJ} / \mathrm{m}^{3} \\
\mathrm{MJ} / \mathrm{kg}\end{array}$ & \multicolumn{3}{|c|}{33.5} & \multicolumn{2}{|c|}{21.1} \\
\hline 9.Operating costs & $\begin{array}{l}\% \text { of in- } \\
\text { vestments }\end{array}$ & \multicolumn{5}{|c|}{3.5} \\
\hline 10.Depreciation costs & $\begin{array}{c}\% \text { of in- } \\
\text { vestments }\end{array}$ & \multicolumn{5}{|c|}{6} \\
\hline
\end{tabular}
carriers was determined as a function of the transportation distance.

Table 1. Accepted technical and economic indices of pipeline. 
Table 2. Accepted technical and economic indices of HVDC lines.

\begin{tabular}{|l|c|c|}
\hline \multicolumn{1}{|c|}{ Indices } & Units & Values \\
\hline 1.Specific investments in overhead line & thousand USD/km & 345 \\
\hline 2.Specific investments in converter substation & USD/kW & 2 \\
\hline 3.Power losses in converter substations & $\%$ & 2800 \\
\hline 4.Total section of wires of one pole & $\mathrm{mm}^{2}$ & 3.75 \\
\hline $\begin{array}{l}\text { 5. Yearly power losses in overhead line at rated power output and } \\
\text { nominal number of utilization hours }\end{array}$ & $\%$ / thousand km & 3000 \\
\hline 6.Rated power output & MW & 6000 \\
\hline 7.Number of capacity utilization hours per year & hours & 80 \\
\hline 8.Investments in infrastructure & & 0.5 \\
\hline $\begin{array}{l}\text { 9. Operating costs: } \\
\text { overhead line } \\
\text { converter substation }\end{array}$ & $\%$ of investments & 2.0 \\
\hline 10.Depreciation costs & \% of investments & 6 \\
\hline
\end{tabular}

Determination of the range of prices of electricity produced by environmentally sound thermal power plants which are considered as closing ones in the NEA countries is an initial premise. The lower limit of the range is determined for thermal power plants on the local coal at a price of $20 \mathrm{USD} / \mathrm{t}$ c.e. and the upper limit - for thermal power plants on imported coal at a price of 70 USD/t c.e. In this case according to calculations the prices of electricity produced at local environmentally sound coal-fired power plants range between 7.8-9.3 cent $/ \mathrm{kWh}$ at IRR equal to $16 \%$. To be competitive the range of prices of power transmitted from the Asian regions of Russia should be taken equal to 7.2-8.4 cent $/ \mathrm{kWh}$, i.e. $10 \%$ lower than that at local coal-fired plants.

Then the required range of natural gas prices was determined for the combined-cycle power plants which will provide the indicated range of prices of electricity produced by them $(7.2-8.4 \mathrm{cent} / \mathrm{kWh}$ at IRR equal to $16 \%$ ). This range made up 152-218 USD/thousand $\mathrm{m}^{3}$ (133-189 USD/t c.e.) and was taken as the basic one for the NEA countries.

The key technical and economic indices applied in calculations are given in Table 3 .

Table 3. Accepted techno-economic indices of combined-cycle power plants.

\begin{tabular}{|l|c|c|}
\hline \multicolumn{1}{|c|}{ Indices } & Units & Values \\
\hline $\begin{array}{l}\text { 1.Specific investments } \\
\text { in per-unit net capacity }\end{array}$ & $\mathrm{USD} / \mathrm{kW}$ & $\begin{array}{c}\text { TPP on } \\
\text { natural gas }\end{array}$ \\
\hline $\begin{array}{l}\text { 2.Specific consumption } \\
\text { of fuel equivalent (net) }\end{array}$ & $\mathrm{g}$ c.e./kWh & 900 \\
\hline 3.Operating costs & \% of investments & 3.5 \\
\hline 4.Depreciation costs & $\%$ of investments & 6 \\
\hline $\begin{array}{l}\text { 5.Number of installed } \\
\text { capacity utilization } \\
\text { hours }\end{array}$ & hours & 6000 \\
\hline
\end{tabular}

The range of methanol prices for the NEA countries was determined based on the following reasons. As to the consumer properties methanol can compete with liquid and motor fuels. The world's practice shows that the fuel prices in terms of energy equivalent are approximately $10-15 \%$ higher than the natural gas prices. Thus, the range of methanol prices will make up 153-217 USD/ t c.e. or 110-156 USD/t of natural methanol, when it is used as an energy fuel. The competitive prices of energy carriers are presented in Table 4.

Table 4. Competitive prices of energy resources.

\begin{tabular}{|c|c|c|c|}
\hline Prices & Units & Min & Max \\
\hline 1. Coal price & USD/t c.e. & 20 & 70 \\
\hline $\begin{array}{l}\text { 2. Price of electricity } \\
\text { produced by coal- } \\
\text { fired power plant }\end{array}$ & cent $/ \mathrm{kWh}$ & 7.8 & 9.3 \\
\hline $\begin{array}{l}\text { 3. Competitive price } \\
\text { of exported electricity }\end{array}$ & cent $/ \mathrm{kWh}$ & 7.2 & 8.4 \\
\hline $\begin{array}{l}\text { 4. Competitive price } \\
\text { of natural gas }\end{array}$ & $\begin{array}{l}\text { USD/thousand } \mathrm{m}^{3} \\
\text { USD/t c.e. }\end{array}$ & $\begin{array}{l}152 \\
133 \\
\end{array}$ & $\begin{array}{l}218 \\
189\end{array}$ \\
\hline $\begin{array}{l}\text { 5. Competitive price } \\
\text { of methanol }\end{array}$ & $\begin{array}{c}\mathrm{USD} / \mathrm{t} \\
\mathrm{USD} / \mathrm{t} \text { c.e. }\end{array}$ & $\begin{array}{l}110 \\
153 \\
\end{array}$ & $\begin{array}{l}156 \\
217 \\
\end{array}$ \\
\hline
\end{tabular}

To determine the IRR for these energy carriers depending on the transportation distance the following options were considered (notation of the variants, used in the below diagrams, is given in brackets).

1. Transport of natural gas by a $1420 \mathrm{~mm}$ pipeline (GPL1420).

2. Transport of natural gas by a $1020 \mathrm{~mm}$ pipeline (GPL1020).

These options of gas pipelines are considered in the basic projects on gas transport from the Asian regions of Russia to the NEA countries.

3. Methanol production from natural gas at the energy-technological installation and its transport by the methanol pipeline (ETIg+ MPL).

4. Electricity production at the combined-cycle power plants on natural gas and its transmission by HVDC lines (TPPg+HVDC).

Tables 1-3 present initial information for calculations. The initial information on ETI is given in Table 5. The electricity price supplied to ETI was taken to be 4.8 cent $/ \mathrm{kWh}$ which corresponds to the electricity price from the combined-cycle power plants on natural gas at a price of $30 \mathrm{USD} /$ thousand $\mathrm{m}^{3}$ [7-15]. 


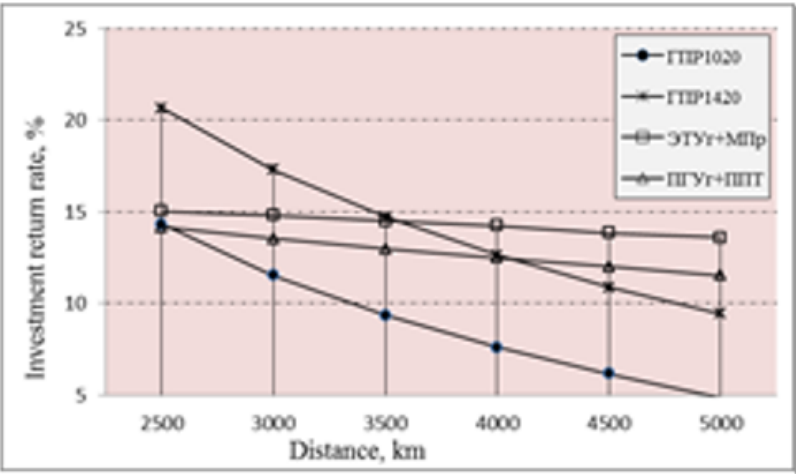

a)

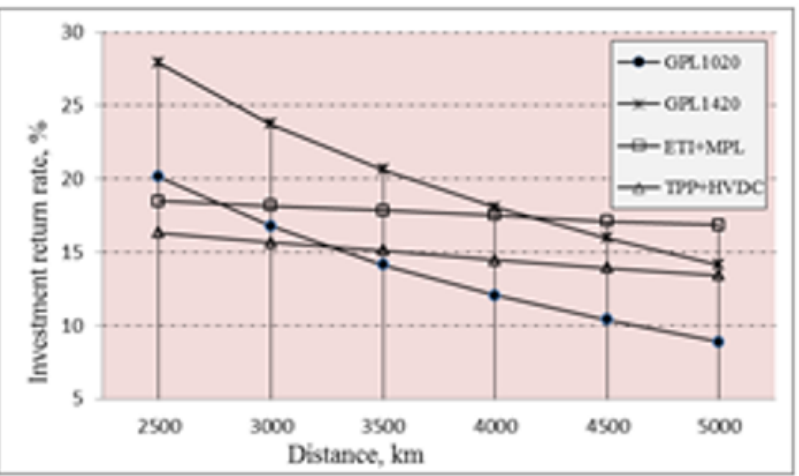

b)

Fig. 1. IRR dependence on energy transportation distance ( $a$ - the lower limit of energy cost range, $b$ - the upper limit of energy cost range).

Table 5. Initial data on ETI for methanol production.

\begin{tabular}{|c|c|c|}
\hline Indices & Units & Value \\
\hline & & $\begin{array}{c}\text { ETI on } \\
\text { gas }\end{array}$ \\
\hline $\begin{array}{l}\text { 1.Yearly } \\
\text { consumption: } \\
\text { equivalent, } \\
\text { natural }\end{array}$ & $\begin{array}{c}\text { thousand t c.e., } \\
\text { million } \mathrm{m}^{3}\end{array}$ & $\begin{array}{l}2480 \\
2100\end{array}$ \\
\hline $\begin{array}{l}\text { 2. Yearly production of } \\
\text { methanol: } \\
\text { equivalent, } \\
\text { natural }\end{array}$ & $\begin{array}{l}\text { thousand t c.e., } \\
\text { thousand } t\end{array}$ & $\begin{array}{l}1395 \\
1936\end{array}$ \\
\hline 3.Yearly electricity output & million $\mathrm{kWh}$ & 2236 \\
\hline 4.Investments in ETI & million USD & 680 \\
\hline 5.Operating costs & $\begin{array}{c}\% \text { of } \\
\text { investments }\end{array}$ & 4.5 \\
\hline 6.Depreciation costs & $\begin{array}{c}\% \text { of } \\
\text { investments }\end{array}$ & 3.5 \\
\hline $\begin{array}{l}\text { 7.Number of yearly } \\
\text { capacity utilization hours }\end{array}$ & hours & 7000 \\
\hline
\end{tabular}

The base specific cost of a linear part of pipelines was used in options 1-3.

At this stage of studies an optimization problem, in which IRR is maximized at the set energy cost values as distinct from problem (1-4), was tackled. The optimization problem in this case is stated in the following form

$$
\max _{Q, x} \operatorname{IRR}\left(C_{e n}, Q, x, y, s\right)
$$

subject to

$$
H(Q, x, y, s)=0
$$

$$
G(Q, x, y, s) \geq 0
$$

Note that when the statements of optimization problems (1-4) and (5-7) based on application of the IRR index are used, there is no need to reduce the options compared to the identical energy effect $[3,12]$.

\section{Conclusions}

Figures 1 illustrate the IRR dependences on the distance of energy resources transport for the analyzed options.

It is seen from the diagrams that starting with distances of $3500-4200 \mathrm{~km}$ the option of methanol production from natural gas and its pipeline transport has higher economic efficiency as compared to the option of natural gas transport by the $1420 \mathrm{~mm}$ pipeline.

The option of electricity production from gas at the combined-cycle installations and its transmission by the HVDC line starting with distances of 2500-3200 is more attractive than the natural gas transport by the $1020 \mathrm{~mm}$ pipeline.

It should be emphasised that the considered options of energy transport substantially differ in the volumes of primary energy resource consumed. In option 1, for example, the yearly natural gas consumption amounts to 40 billion $\mathrm{m} 3$, in option 2 - 10 billion $\mathrm{m} 3$. For methanol production at ETI and further transport of 100 billion $t$ of methanol gas consumption in option 3 reaches 108 billion $\mathrm{m} 3$ per year. Gas consumption for power generation in option 4 accounts for 3.5 billion $\mathrm{m} 3$ per year.

The economic efficiency of projects on energy resources export at long distances substantially depends on the proper choice of transportation technology. The options of methanol and electricity transport become more preferable with increasing distances. In this case the methanol pipeline transport allows an effective arrangement of powerful energy flows at substantial distances and the railway transport and the HVDC transmission - relatively small energy flows at long distances.

The research was carried out under State Assignment, Project 17.1.1 (reg. no. AAAA-A17-117030310433-6) of the Fundamental Research of Siberian Branch of the Russian Academy of Sciences and partly supported by the Russian Foundation of Basic Research, Grant No. 18-08-01184 A. 


\section{References}

[1] A.M. Kler, N.P. Dekanova, E.A. Tyurina, et al Novosibirsk Nauka 236 (in Rusian) (2005)

[2] A.M. Kler, E.A. Tyurina, Optimization Studies of Power Plants and Energy Complexes ed (Novosibirsk: Academic Publishing House Geo) 298 (in Rusian) (2016)

[3] P.L. Vilensky, V.I. Livshits, S.A. Smolyak, (M.: Delo) 832, (in Russian) (2001)

[4] Z. Yaru, Yu. Yadong, M. Tieju, Journal of Renewable and Sustainable Energy 045503, 10 (2018)

[5] J.Pan, Power Syst.Clean Energy 27, 1-3 (2011)

[6] Z. Yang, T. Hongbo, L. Yanzhong, Z. Jieyu W. Chunyan, Energy 77, 710-719 (2014)

[7] A.M. Kler, E.A. Tyurina, A.S. Mednikov, International Journal of Hydrogen Energy 36(1), 123035 (2011)

[8] M.K. Aleksandr, A.T. Elina, S.M. Aleksandr, Energy 165, 890-9 (2018)

[9] H. Lin, H. Jin, L. Gao, W. Han, Energy 35, 858-63 (2010)

[10] N. Schmitz, J. Burger, Fuel 185, 67-72 (2016)

[11] A.M. Kler, P.V. Zharkov, N.O. Epishkin, Thermophysics Aeromechanics 23(2), 289-296 (2016)

[12] G.G. Olkhovsky, Teploenergetika 1, 2-9 (in Rusian) (2006)

[13] E. Tyurina, A. Mednikov, O. Skripchenko, Presco Proc The Energy Debate: Challenges \& Alternatives 101-106 (2012)

[14] N. Schmitz, J. Burger, Fuel 185, 67-72 (2016)

[15] M. Azadi, N. Tahouni, M.H. Panjeshahi, Applied Thermal Engineering 107, 1324-33 (2016) 